\title{
Neptunomonas japonica sp. nov., an Osedax japonicus symbiont-like bacterium isolated from sediment adjacent to sperm whale carcasses off Kagoshima, Japan \\ Correspondence \\ Masayuki Miyazaki \\ miyazakim@jamstec.go.jp \author{
Kaoru Kubokawa ${ }^{2}$ and Koki Horikoshi ${ }^{1}$ \\ ${ }^{1}$ Extremobiosphere Research Center, Japan Agency for Marine-Earth Science and Technology \\ (JAMSTEC), 2-15 Natsushima-cho, Yokosuka 237-0061, Japan \\ ${ }^{2}$ Center for Advanced Marine Research, Ocean Research Institute, The University of Tokyo, \\ 1-15-1 Minamidai, Nakano-ku, Tokyo 164-8639, Japan
} \\ Masayuki Miyazaki, ${ }^{1}$ Yuichi Nogi, ${ }^{1}$ Yoshihiro Fujiwara, ${ }^{1}$ Masaru Kawato, ${ }^{1}$

\begin{abstract}
Novel bacterial species were isolated from sediments adjacent to sperm whale carcasses off Kagoshima, Japan, at a depth of 226-246 m. The isolated strains, JAMM $0745^{\top}$, JAMM 1380, JAMM 1475 and JAMM 1610, were Gram-negative, rod-shaped, non-spore-forming and motile by means of a single polar or subterminal flagellum. Phylogenetic analysis based on 16S rRNA gene sequences of the novel isolates indicated a relationship to a symbiotic bacterial clone of the polychaete Osedax japonicus (99.6-99.9\% sequence similarity) and these bacteria were closely related to members of the genus Neptunomonas (95.6-96.0\% similarity) within the class Gammaproteobacteria. The novel strains were able to produce isoprenoid quinone Q-8 as the major quinone component. The predominant fatty acids were $C_{16: 0}, C_{16: 1}$ and $C_{18: 1}$, with $C_{18: 2}$ and $\mathrm{C}_{20: 2}$ present in smaller amounts. The DNA $G+C$ contents of the four novel strains were about 43.6-43.8 mol\%. Based on the taxonomic differences observed, the four isolated strains appear to represent a novel species of the genus Neptunomonas. The name Neptunomonas japonica sp. nov. (type strain JAMM $0745^{\top}=\mathrm{JCM} 14595^{\top}=\mathrm{DSM} 18939^{\top}$ ) is proposed for the novel strains.
\end{abstract}

The type species of the genus Neptunomonas was described as a rod-shaped, Gram-negative, facultatively aerobic gammaproteobacterium with a single polar flagellum (Hedlund et al., 1999) and was isolated from creosotecontaminated sediment from Puget Sound. The polycyclic aromatic hydrocarbon-degrading Neptunomonas naphthovorans is currently the only species in this genus. The genus Neptunomonas is most closely related to the genera Oceanospirillum and Neptuniibacter and to a symbiotic bacterial clone of the genus Osedax (Hedlund et al., 1999; Arahal et al., 2007; Goffredi et al., 2007). The genus Osedax, composed of siboglinid polychaeta, has recently been discovered in whale carcasses on the deep-sea floor (Rouse et al., 2004; Glover et al., 2005; Fujikura et al., 2006). Members of the genus Osedax host symbiotic bacteria in the ovisac and root systems. Phylogenetic analysis placed the micro-organisms isolated from Osedax

Abbreviation: ASW, artificial seawater.

The GenBank/EMBL/DDBJ accession numbers for the 16S rRNA gene sequences acquired during this study are AB288092, AB291226AB291228 and AB293969-AB293970. sp. within a well-supported clade of Gammaproteobacteria associated with heterotrophic members of the order Oceanospirillales (Goffredi et al., 2007). Neptunomonas naphthovorans is the closest cultured relative (93-94\% $16 \mathrm{~S}$ rRNA gene sequence similarity) to the Osedax symbionts (Goffredi et al., 2005). We investigated a sperm whale carcass ecosystem off Kagoshima, Japan, for three years (Fujiwara et al., 2007). About 800 aerobic bacteria were isolated from the sediment adjacent to the sperm whale carcasses, of which four strains were related to the symbiont-like bacteria clone of Osedax japonicus and to members of the genus Neptunomonas. In this paper, we characterize and describe four strains isolated from the sediment adjacent to the sperm whale carcasses that are members of the class Gammaproteobacteria and are related to the symbiont-like bacteria clone of Osedax japonicus and the genus Neptunomonas.

The four strains, JAMM $0745^{\mathrm{T}}$, JAMM 1380, JAMM 1475 and JAMM 1610, were isolated from the sediment adjacent to the whale carcasses, especially adjacent to the cephalic soft tissues, by the unmanned ROV Hyper Dolphin off Kagoshima, Japan (dive no. 331, 31 $20.991^{\prime} \mathrm{N} 129^{\circ}$ 
59.160' E; dive no. $452,31^{\circ} 20.997^{\prime} \mathrm{N} 129^{\circ} 59.162^{\prime} \mathrm{E}$; dive no. $456,31^{\circ} 20.997^{\prime} \mathrm{N} 129^{\circ} 59.158^{\prime} \mathrm{E}$ and dive no. $458,31^{\circ}$ $18.842^{\prime} \mathrm{N} 129^{\circ} 59.521^{\prime} \mathrm{E}$ ) at a depth of 226-246 m during cruises NT04-08 and NT05-12. The sediment samples were collected by the ROV's manipulator and placed in the sample holder of the sterilized sampler. A portion of each sample was cultivated on marine agar 2216 (MA; Difco) at $12{ }^{\circ} \mathrm{C}$ for approximately 7 days. The bacteria were maintained on MA plates or in marine broth 2216 (MB; Difco) at $20{ }^{\circ} \mathrm{C}$ and stored at $-80{ }^{\circ} \mathrm{C}$ in $15 \%(\mathrm{v} / \mathrm{v})$ glycerol. Neptunomonas naphthovorans ATCC $700637^{\mathrm{T}}$ was used as a reference strain. Unless otherwise indicated, physiological tests were performed with a slight modification of the general procedures described by Barrow \& Feltham (1993) and Baumann et al. (1972) that used artificial seawater (ASW; $1 \times$ ASW consisted of $2.75 \% \mathrm{NaCl}, 0.07 \% \mathrm{KCl}$, $0.54 \% \quad \mathrm{MgCl}_{2} \cdot 6 \mathrm{H}_{2} \mathrm{O}, \quad 0.68 \% \quad \mathrm{MgSO}_{4} \cdot 7 \mathrm{H}_{2} \mathrm{O}, \quad 0.14 \%$ $\mathrm{CaCl}_{2} \cdot 2 \mathrm{H}_{2} \mathrm{O}$ and $0.02 \% \mathrm{NaHCO}_{3}$ ).

Transmission electron microscopy of negatively stained cells was conducted as described by Nogi et al. (1998). Cells of strain JAMM $0745^{\mathrm{T}}$ grown on MA at optimal temperature and in the mid-exponential phase of growth were used for electron microscopic observations (JEM1210; JEOL).

Growth at various temperatures $\left(0-30{ }^{\circ} \mathrm{C}\right)$ was measured in MB. The test strains retained viability for about 7 days at optimal temperature. Growth at various $\mathrm{NaCl}$ concentrations was examined in medium containing $0.5 \%$ peptone (Difco), $0.5 \%$ yeast extract (Difco) and $0.32 \%$ $\mathrm{MgSO}_{4} \cdot 7 \mathrm{H}_{2} \mathrm{O}$, with $\mathrm{NaCl}$ concentrations of $0-6 \%(\mathrm{w} / \mathrm{v})$. The optimal $\mathrm{pH}$ and $\mathrm{pH}$ range for growth were determined in $0.5 \%$ peptone, $0.5 \%$ yeast extract, $0.32 \%$ $\mathrm{MgSO}_{4} \cdot 7 \mathrm{H}_{2} \mathrm{O}$ and $3.0 \% \mathrm{NaCl}(\mathrm{w} / \mathrm{v})$ with the $\mathrm{pH}$ adjusted to $6.0,6.5,7.0,7.5,8.0,8.5$ and 9.0. Acid production from sugars was assessed using modified $\mathrm{O} / \mathrm{F}$ (oxidizationfermentation) medium (Hugh \& Leifson, 1953) containing $0.5 \times$ ASW, $0.1 \%\left(\mathrm{NH}_{4}\right)_{2} \mathrm{SO}_{4}, 0.1 \%$ yeast extract (Difco), $0.1 \%$ Tris, $1.4 \% \mathrm{NaCl}, 1 \%$ sugar and $0.006 \%$ bromothymol blue ( $\mathrm{pH}$ adjusted to 7.2 at $20{ }^{\circ} \mathrm{C}$ ) and incubated at the optimum temperature. Oxidase activity was determined by spreading cell pellets on oxidase test paper (Nissui Pharmaceutical). Catalase activity was determined based on bubble production in $3 \%(\mathrm{v} / \mathrm{v}) \mathrm{H}_{2} \mathrm{O}_{2}$ solution. Gelatinase, protease, amylase and lipase activities were detected on MA plates using substrate concentrations of $1 \%$. Urease activity was detected using the method described by Maslen (1952) and DNase activity was assessed using DNase test agar (Difco). Hydrogen sulfide production from thiosulfate and the production of indole were assessed using sulfide indole motility agar (Nissui Pharmaceutical) stabs prepared with $0.5 \times$ ASW instead of water. Susceptibility to antimicrobial substances was examined on MA using Sensi-Discs (Becton Dickinson). Any sign of growth inhibition after $48 \mathrm{~h}$ incubation at $20{ }^{\circ} \mathrm{C}$ was recorded as sensitivity to the respective antimicrobial agent. The following antibiotics (Becton Dickinson) were examined: ampicillin $(10 \mu \mathrm{g})$, chloramphenicol $(30 \mu \mathrm{g})$, erythromycin $(15 \mu \mathrm{g})$, gentamicin $(10 \mu \mathrm{g})$, kanamycin $(30 \mu \mathrm{g})$, nalidixic acid $(30 \mu \mathrm{g})$, neomycin $(30 \mu \mathrm{g})$, novobiocin $(30 \mu \mathrm{g})$, penicillin $(10 \mathrm{U})$, streptomycin $(10 \mu \mathrm{g})$, and tetracycline $(30 \mu \mathrm{g})$.

Cellular fatty acids were extracted and analysed as described by Komagata \& Suzuki (1987). Isolated strains and Neptunomonas naphthovorans ATCC $700637^{\mathrm{T}}$ were cultured in $\mathrm{MB}$ at the optimal temperatures. Fatty acids were extracted using the method of Miyazaki et al. (2006). Isoprenoid quinones were extracted with chloroform/ methanol (2:1) from dried cells $(200 \mathrm{mg})$ and purified by TLC. The purified isoprenoid quinones were analysed using reversed-phase high-performance liquid chromatography (HPLC) (Komagata \& Suzuki, 1987).

Chromosomal DNA was purified using the standard method (Saito \& Miura, 1963). The DNA G + C content was determined using reversed-phase HPLC (Tamaoka \& Komagata, 1984). For analysis of relatedness, DNA-DNA hybridization was carried out at $42{ }^{\circ} \mathrm{C}$ for $4 \mathrm{~h}$ and measured fluorometrically according to the method of Ezaki et al. (1989).

The 16S rRNA gene was amplified using the PCR method with primers 27F and 1492R (Lane, 1991). The PCR product was sequenced with the dideoxynucleotide chaintermination method, using a DYEnamic ET terminator (MegaBACE) reagent premix (GE Healthcare UK Ltd) and a MegaBACE 1000 DNA sequencer (GE Healthcare UK Ltd). Primers 27F, 350F, 520R, 780F, 907R, 1100F and $1492 \mathrm{R}$ were used in the gene sequencing reaction. Nucleotide substitution rates $\left(K_{\text {nuc }}\right)$ (Kimura, 1980) were determined and a distance matrix tree was constructed with the neighbour-joining method (Saitou \& Nei, 1987) using the CLUSTAL_X program (Thompson et al., 1997). The topology of the phylogenetic tree was evaluated by performing bootstrap analysis with 1000 replicates. The GenBank/DDBJ/EMBL accession numbers for the $16 \mathrm{~S}$ rRNA gene sequences of the isolates are shown in Fig. 1. Other reference sequences were obtained from the GenBank database.

Colonies on MA were circular with entire edges, smooth, convex and cream coloured and were 0.5 to $1.0 \mathrm{~mm}$ in diameter after 1-2 days of incubation at $20{ }^{\circ} \mathrm{C}$. Cells of the four novel strains were found to be Gram-negative rods, $1.6-1.8 \mu \mathrm{m}$ long and $0.8-1.0 \mu \mathrm{m}$ wide and were motile by means of a single, unsheathed, subterminal flagellum (Fig. 2).

Culture, physiological and biochemical characteristics of the isolates are shown in Table 1 or given in the species descriptions below. The novel strains were facultative anaerobes and were capable of respiratory metabolism. Growth occurred at temperatures from 5 to $25{ }^{\circ} \mathrm{C}$, with an optimum of $20{ }^{\circ} \mathrm{C}$. No growth occurred at temperatures higher than $27{ }^{\circ} \mathrm{C}$. Growth occurred at $\mathrm{NaCl}$ concentrations of $1-5 \%$, but not in the absence of $\mathrm{NaCl}$, and the optimal concentration for growth was $2 \%$. Growth 


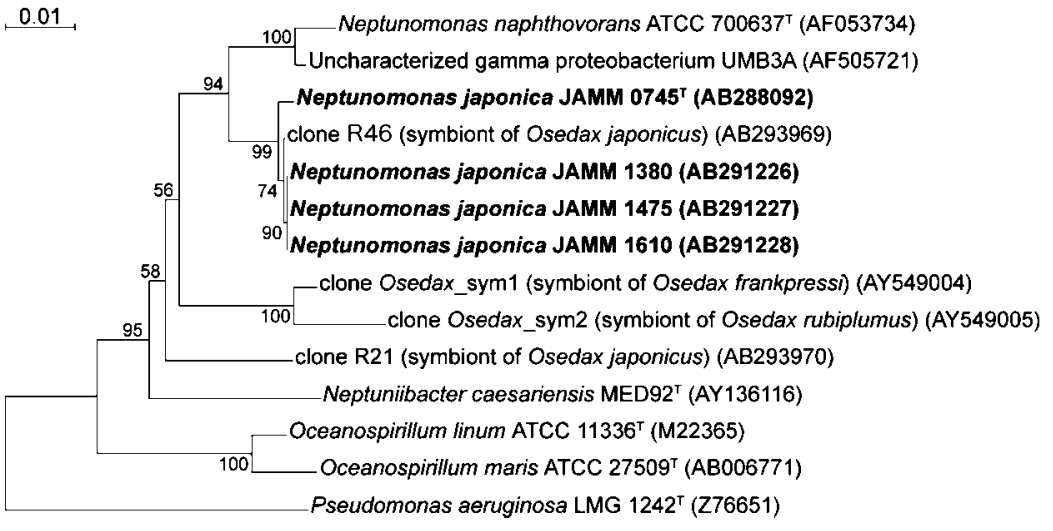

Fig. 1. Phylogenetic tree constructed using the neighbour-joining method and based on $16 S$ rRNA gene sequences showing the relationships of strain JAMM $0745^{\top}$ within the genus Neptunomonas and related genera. Bootstrap values were calculated from multiple resamplings of the sequence dataset, which are the basis for multiple tree topologies. Bar, 0.01 nucleotide substitution per site. occurred at $\mathrm{pH}$ values ranging from 7.0 to 8.5. No growth occurred at $\mathrm{pH}$ values greater than 9.0. Catalase, cytochrome oxidase, gelatinase, DNase and lipase (hydrolysis of tri- $n$-butyrin) tests were positive. Protease, amylase, agarase and urease tests were negative. Aesculin was not hydrolysed. $\mathrm{H}_{2} \mathrm{~S}$ and indole were not produced. Reduction of nitrate to nitrite occurred. Acid was not formed oxidatively from sugar. When the four isolated strains were analysed for their susceptibility to 11 antimicrobial compounds, all displayed susceptibility to the same compounds, varying only in the diameters of the zones of inhibition. They were susceptible to ampicillin $(10 \mu \mathrm{g})$, chloramphenicol $(30 \mu \mathrm{g})$, erythromycin $(15 \mu \mathrm{g})$, gentamicin $(10 \mu \mathrm{g})$, kanamycin $(30 \mu \mathrm{g})$, nalidixic acid $(30 \mu \mathrm{g})$, neomycin $(30 \mu \mathrm{g})$, penicillin (10 IU) and streptomycin $(10 \mu \mathrm{g})$. No inhibition zones were detected around the discs containing novobiocin $(30 \mu \mathrm{g})$ or tetracycline $(30 \mu \mathrm{g})$. The isoprenoid quinones of both the newly isolated strains and Neptunomonas naphthovorans ATCC $700637^{\mathrm{T}}$ were the respiratory quinones detected, with Q-8 (99\%) predominating and Q-9 (1\%) present in minor amounts.

The results of the phylogenetic analyses using 16S rRNA gene sequences are shown in Fig. 1. These results support

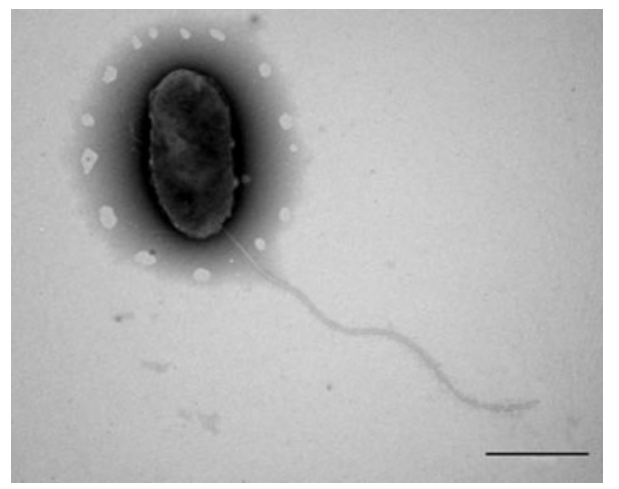

Fig. 2. Electron micrograph of a negatively stained cell of strain JAMM $0745^{\top}$. Bar, $1.0 \mu \mathrm{m}$. the conclusions described below and further clarify the taxonomic and phylogenetic positions of the four isolated strains. The four novel strains showed high sequence similarities to the following species or genera: Neptunomonas naphthovorans ATCC $700637^{\mathrm{T}}(95.6-96.0 \%)$, the genus Oceanospirillum (92.3-93.5\%) and Neptuniibacter

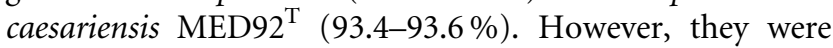
more closely related to the $16 \mathrm{~S}$ rRNA gene sequences of the symbiotic bacterial clone R46 of Osedax japonicus (99.6$99.9 \%$ ) and to the sequence of the uncharacterized strain UMB3A (96.0-96.4\%) isolated from Boston Harbor surface water. The generally recommended and accepted criteria for delineating bacterial species state that strains with $16 \mathrm{~S}$ rRNA gene sequence dissimilarity of greater than $3 \%$ are considered to belong to separate species (Stackebrandt \& Goebel, 1994; Stackebrandt et al., 2002). Phylogenetic analysis revealed that the $16 \mathrm{~S}$ rRNA gene sequence of strain JAMM $0745^{\mathrm{T}}$ was grouped with the symbiotic bacterial clone sequence of Osedax japonicus, the related strain Neptunomonas naphthovorans ATCC $700637^{\mathrm{T}}$ and the uncharacterized strain UMB3A. These strains were included in the sequences of species representing the genus Neptunomonas. The results of DNA-DNA hybridization analysis showed that the four isolated strains showed more than $72 \%$ DNA-DNA relatedness with each other, but DNA-DNA relatedness values between these strains and Neptunomonas naphthovorans ATCC $700637^{\mathrm{T}}$ were less than $12 \%$ and each group was clearly separate, representing distinct species according to the recommendations of Wayne et al. (1987). The G $+C$ content of the DNA of the four novel strains was $43.6-43.8 \mathrm{~mol} \%$.

The whole-cell fatty acid contents of the novel strain JAMM $0745^{\mathrm{T}}$, Neptunomonas naphthovorans ATCC $700637^{\mathrm{T}}$ and reference strains are shown in Table 2. The major fatty acids of strain JAMM $0745^{\mathrm{T}}$ were $\mathrm{C}_{16: 1}$ (hexadecenoic acid) and $\mathrm{C}_{18: 1}$ (octadecenoic acid) and the major 3-hydroxy fatty acid was $\mathrm{C}_{10: 0}$. For Neptunomonas naphthovorans ATCC $700637^{\mathrm{T}}, \mathrm{C}_{16: 0}$ (hexadecanoic acid), $\mathrm{C}_{16: 1}$ and $\mathrm{C}_{18: 1}$ were the major fatty acids with $\mathrm{C}_{10: 0}$ as the major 3-hydroxy fatty acid. The fatty acid profile of strain JAMM $0745^{\mathrm{T}}$ showed low levels of similarity to those of the reference strains. For example, strain JAMM $0745^{\mathrm{T}}$ 
Table 1. Differential characteristics of strain JAMM $0745^{\top}$ and related taxa

Taxa: 1, Neptunomonas japonica sp. nov. JAMM $0745^{\mathrm{T}}$; 2, Neptunomonas naphthovorans ATCC $700637^{\mathrm{T}}$; 3 , Oceanospirillum linum ATCC $11336^{\mathrm{T}}$; 4 , Neptuniibacter caesariensis MED92 ${ }^{\mathrm{T}}$. All taxa are motile, amylase-negative and catalase- and oxidase-positive. + , Positive; - , negative; ND, no data. Data are from this study, Arahal et al. (2007), Garrity et al. (2005), Hedlund et al. (1999), Holt et al. (1994), Krieg (1984), Labrenz et al. (2003), Sakane \& Yokota (1994) and Satomi et al. (2002).

\begin{tabular}{|c|c|c|c|c|}
\hline Characteristic & 1 & 2 & 3 & 4 \\
\hline Cell shape & Rods & Rods & Spirillum & Rods \\
\hline Length $\times$ width & $1.6-1.8 \times 0.8-1.0$ & $2.0-3.0 \times 0.7-0.9$ & $1.8-4.0 \times 0.8-1.4$ & $1.5-2.3 \times 0.5-0.8$ \\
\hline Coccoid body formation & - & ND & + & + \\
\hline \multicolumn{5}{|l|}{ Growth at/in: } \\
\hline $30{ }^{\circ} \mathrm{C}$ & - & - & + & + \\
\hline Gelatinase & + & - & + & - \\
\hline Protease & - & ND & - & - \\
\hline Urease & - & ND & - & ND \\
\hline DNase & + & - & - & - \\
\hline Lipase & + & - & ND & - \\
\hline Hydrolysis of aesculin & - & ND & - & ND \\
\hline Acid production from sugars & - & + & - & ND \\
\hline DNA G + C content $(\mathrm{mol} \%)$ & 43.6 & 46.3 & $48-50$ & 46.6 \\
\hline
\end{tabular}

Table 2. Fatty acid contents of the novel isolate JAMM $0745^{\top}$ and reference strains

1, Neptunomonas japonica sp. nov. JAMM $0745^{\mathrm{T}} ; 2$, Neptunomonas naphthovorans ATCC $700637^{\mathrm{T}}$; 3, Oceanospirillum linum NBRC $15448^{\mathrm{T}} ; 4$, Neptuniibacter caesariensis MED92 ${ }^{\mathrm{T}}$. tr, Trace $(<1 \%)$. Data are from this study, Arahal et al. (2007), Labrenz et al. (2003) and Sakane \& Yokota (1994).

\begin{tabular}{|lcccc|}
\hline Fatty acid & $\mathbf{1}$ & $\mathbf{2}$ & $\mathbf{3}$ & $\mathbf{4}$ \\
\hline Nonpolar $^{\star}$ & & & & \\
$\mathrm{C}_{10: 0}$ & & & & $\operatorname{tr}$ \\
$\mathrm{C}_{12: 0}$ & & 7 & 3 & \\
$\mathrm{C}_{12: 1}$ & 3 & 4 & 2 & \\
$\mathrm{C}_{14: 0}$ & & & 1 & $\operatorname{tr}$ \\
$\mathrm{C}_{16: 0}$ & 11 & 21 & 16 & 17 \\
$\mathrm{C}_{16: 1}$ & 51 & 41 & 48 & 44 \\
$\mathrm{C}_{18: 0}$ & $\operatorname{tr}$ & $\operatorname{tr}$ & & 1 \\
$\mathrm{C}_{18: 1}$ & 27 & 28 & 30 & 38 \\
$\mathrm{C}_{18: 2}$ & 5 & & & \\
$\mathrm{C}_{20: 2}$ & 2 & & & \\
$3-\mathrm{Hydroxy} \dagger$ & & & & \\
$\mathrm{C}_{10: 0}$ & 100 & 100 & 100 & 100 \\
\hline
\end{tabular}

${ }^{\star}$ Numbers refer to the percentage of an acid relative to the total nonpolar fatty acids.

$\dagger$ Numbers refer to the percentage of an acid relative to the total hydroxy fatty acids. contained relatively large amounts of $\mathrm{C}_{16: 1}$ and small amounts of $\mathrm{C}_{16: 0} \cdot \mathrm{C}_{18: 2}$ (octadecadienoic acid) and $\mathrm{C}_{20: 2}$ (eicosadienoic acid) were produced, but $\mathrm{C}_{12: 0}$ (dodecanoic acid) was not produced.

The similarity of the four novel strains to the Osedax symbiont-like bacteria was estimated based on the basis of the phenotypic, genotypic and phylogenetic data and it is evident that they represent a novel species within the genus Neptunomonas. We suggest that strains JAMM $0745^{\mathrm{T}}$, JAMM 1380, JAMM 1475 and JAMM 1610 represent a novel species, for which the name Neptunomonas japonica sp. nov. is proposed.

\section{Description of Neptunomonas japonica sp. nov.}

Neptunomonas japonica (ja.po'ni.ca. N.L. fem. adj. japonica Japan, pertaining to Japan, where the isolate originated).

Cell are rod-shaped; cell width ranges from 0.8 to $1.0 \mu \mathrm{m}$ and cell length ranges from 1.6 to $1.8 \mu \mathrm{m}$. Cells are Gramnegative and motile by means of a single polar or subterminal flagellum. Colonies on MA are circular with entire edges, smooth, convex, and cream coloured, 0.5 to $1.0 \mathrm{~mm}$ in diameter after 1 to 2 days of incubation at $20{ }^{\circ} \mathrm{C}$. The bacteria are psychrotrophic. The optimal growth temperature is $20{ }^{\circ} \mathrm{C}$. Growth occurs at 5 and $25{ }^{\circ} \mathrm{C}$, but not at $0{ }^{\circ} \mathrm{C}$ or above $27{ }^{\circ} \mathrm{C}$. Optimal growth occurs in the presence of $2 \% \mathrm{NaCl}$. Growth occurs in the presence of $1 \%$ and $5 \% \mathrm{NaCl}$, but not without $\mathrm{NaCl}$ or in the presence of $>6 \% \mathrm{NaCl}$. The optimal 
$\mathrm{pH}$ value for growth is 7.5. Growth occurs at $\mathrm{pH} 7.0$ and $\mathrm{pH} 8.5$, but not at $\mathrm{pH} 6.5$ or greater than $\mathrm{pH} 9.0$. Facultatively anaerobic and capable of respiratory metabolism. The catalase and cytochrome oxidase tests are positive. Does not produce $\mathrm{H}_{2} \mathrm{~S}$ or indole. Nitrate is reduced to nitrite, but nitrite is not reduced. Gelatinase, DNase and lipase activities are positive. Protease, amylase, urease and agarase activities are negative. Acid is not formed oxidatively from sugars. Susceptible to ampicillin $(10 \mu \mathrm{g})$, chloramphenicol $(30 \mu \mathrm{g})$, erythromycin $(15 \mu \mathrm{g})$, gentamicin $(10 \mu \mathrm{g})$, kanamycin $(30 \mu \mathrm{g})$, nalidixic acid $(30 \mu \mathrm{g})$, neomycin $(30 \mu \mathrm{g})$, penicillin (10 $\mathrm{U})$ and streptomycin $(10 \mu \mathrm{g})$, but resistant to novobiocin $(30 \mu \mathrm{g})$ and tetracycline $(30 \mu \mathrm{g})$. The $\mathrm{G}+\mathrm{C}$ content of the DNA is about $43.6-43.8 \mathrm{~mol} \%$ (determined by HPLC). The major isoprenoid quinone is Q-8. The dominant cellular fatty acids are $\mathrm{C}_{16: 0}, \mathrm{C}_{16: 1}$ and $\mathrm{C}_{18: 1}$.

The type strain, JAMM $0745^{\mathrm{T}}\left(=\mathrm{JCM} \quad 14595^{\mathrm{T}}=\mathrm{DSM}\right.$ $\left.18939^{\mathrm{T}}\right)$, was isolated from the sediment adjacent to a sperm whale carcass off Kagoshima, Japan.

\section{Acknowledgements}

We would like to thank Mr Katsuyuki Uematsu for assistance in preparing electron micrographs. We are very grateful to the ROV Hyper Dolphin operation team and the captain and crew of the R/V Natushima for helping to collect the deep-sea samples.

\section{References}

Arahal, D. R., Lekunberri, I., González, J. M., Pascual, J., Pujalte, M. J., Pedrós-Alió, C. \& Pinhassi, J. (2007). Neptuniibacter caesarensis gen. nov., sp. nov., a novel marine genome-sequenced gammaproteobacterium. Int J Syst Evol Microbiol 57, 1000-1006.

Barrow, G. I. \& Feltham, R. K. A. (1993). Cowan and Steel's Manual for the Identification of Medical Bacteria, 3rd edn. Cambridge: Cambridge University Press.

Baumann, L., Baumann, P., Mandel, M. \& Allen, R. D. (1972). Taxonomy of aerobic marine eubacteria. $J$ Bacteriol 110, 402-429.

Ezaki, T., Hashimoto, Y. \& Yabuuchi, E. (1989). Fluorometric deoxyribonucleic acid-deoxyribonucleic acid hybridization in microdilution wells as an alternative to membrane filter hybridization in which radioisotopes are used to determine genetic relatedness among bacterial strains. Int J Syst Bacteriol 39, 224-229.

Fujikura, K., Fujiwara, Y. \& Kawato, M. (2006). A new species of Osedax (Annelida: Siboglinidae) associated with whale carcasses off Kyushu, Japan. Zoolog Sci 23, 733-740.

Fujiwara, Y., Kawato, M., Yamamoto, T., Yamanaka, T., Sato-Okoshi, W., Noda, C., Tsuchida, S., Komai, T., Cubelio, S. S. $\&$ other authors (2007). Three-year investigations into sperm whalefall ecosystems in Japan. Mar Ecol 28, 219-232.

Garrity, G. M., Bell, J. A. \& Lilburn, T. (2005). Family I Oceanospirillaceae fam. nov. In Bergey's Manual of Systematic Bacteriology, 2nd edn., vol. 2 (The Proteobacteria), part B (The Gammaproteobacteria), pp. 271-295. Edited by D. J. Brenner, N. R. Krieg, J. T. Staley \& G. M. Garrity. New York: Springer.

Glover, A. G., Källström, B., Smith, C. R. \& Dahlgren, T. G. (2005). World-wide whale worms? A new species of Osedax from the shallow north Atlantic. Proc Biol Sci 272, 2587-2592.
Goffredi, S. K., Orphan, V. J., Rouse, G. W., Jahnke, L., Embaye, T., Turk, K., Lee, R. \& Vrijenhoek, R. C. (2005). Evolutionary innovation: a bone-eating marine symbiosis. Environ Microbiol 7, 1369-1378.

Goffredi, S. K., Johnson, S. B. \& Vrijenhoek, R. C. (2007). Genetic diversity and potential function of microbial symbionts associated with newly discovered species of Osedax polychaete worms. Appl Environ Microbiol 73, 2314-2323.

Hedlund, B. P., Geiselbrecht, A. D., Bair, T. J. \& Staley, J. T. (1999). Polycyclic aromatic hydrocarbon degradation by a new marine bacterium, Neptunomonas naphthovorans gen. nov., sp. nov. Appl Environ Microbiol 65, 251-259.

Holt, J. G., Krieg, N. R., Sneath, P. H. A., Staley, J. T. \& Williams, S. T. (editors) (1994). Bergey's Manual of Determinative Bacteriology, 9th edn. Baltimore, MD: Williams and Wilkins.

Hugh, R. \& Leifson, E. (1953). The taxonomic significance of fermentative versus oxidative metabolism of carbohydrates by various gram negative bacteria. J Bacteriol 66, 24-26.

Kimura, M. (1980). A simple method for estimating evolutionary rates of base substitutions through comparative studies of nucleotide sequences. J Mol Evol 16, 111-120.

Komagata, K. \& Suzuki, K. (1987). Lipid and cell-wall analysis in bacterial systematics. Methods Microbiol 19, 161-207.

Krieg, N. R. (1984). Aerobic/microaerophilic, motile, helical/vibrioid Gram-negative bacteria. In Bergey's Manual of Systematic Bacteriology, vol. 1, pp. 104-110. Edited by N. R. Krieg \& J. G. Holt. Baltimore, MD: Williams and Wilkins.

Labrenz, M., Lawson, P. A., Tindall, B. J., Collins, M. D. \& Hirsch, P. (2003). Saccharospirillum impatiens gen. nov., sp. nov., a novel $\gamma$ Proteobacterium isolated from hypersaline Ekho Lake (East Antarctica). Int J Syst Evol Microbiol 53, 653-660.

Lane, D. J. (1991). 16S/23S rRNA sequencing. In Nucleic Acid Techniques in Bacterial Systematics, pp. 115-148. Edited by E. Stackebrandt \& M. Goodfellow. Chichester: Wiley.

Maslen, L. G. C. (1952). Routine use of liquid urea medium for identifying Salmonella and Shigella organisms. Br Med J 2, 545-546.

Miyazaki, M., Nogi, Y., Usami, R. \& Horikoshi, K. (2006). Shewanella surugensis sp. nov., Shewanella kaireitica sp. nov. and Shewanella abyssi sp. nov., isolated from deep-sea sediments of Suruga Bay, Japan. Int J Syst Evol Microbiol 56, 1607-1613.

Nogi, Y., Kato, C. \& Horikoshi, K. (1998). Taxonomic studies of deepsea barophilic Shewanella strains and description of Shewanella violacea sp. nov. Arch Microbiol 170, 331-338.

Rouse, G. W., Goffredi, S. K. \& Vrijenhoek, R. C. (2004). Osedax: bone-eating marine worms with dwarf males. Science 305, 668-671.

Saito, H. \& Miura, K. (1963). Preparation of transforming deoxyribonucleic acid by phenol treatment. Biochim Biophys Acta 72, 612-629.

Saitou, N. \& Nei, M. (1987). The neighbor-joining method: a new method for reconstructing phylogenetic trees. Mol Biol Evol 4, 406-425.

Sakane, T. \& Yokota, A. (1994). Chemotaxonomic investigation of heterotrophic, aerobic and microaerophilic spirilla, the genera Aquaspirillum, Magnetospirillum, and Oceanospirillum. Syst Appl Microbiol 17, 128-134.

Satomi, M., Kimura, B., Hamada, T., Harayama, S. \& Fujii, T. (2002). Phylogenetic study of the genus Oceanospirillum based on $16 \mathrm{~S}$ rRNA and gyrB genes: emended description of the genus Oceanospirillum, description of Pseudospirillum gen. nov., Oceanobacter gen. nov. and Terasakiella gen. nov. and transfer of Oceanospirillum jannaschii and Pseudomonas stanieri to Marinobacterium as Marinobacterium jan- 
naschii comb. nov. and Marinobacterium stanieri comb. nov. Int J Syst Evol Microbiol 52, 739-747.

Stackebrandt, E. \& Goebel, B. M. (1994). Taxonomic note: a place for DNA-DNA reassociation and $16 \mathrm{~S}$ rRNA sequence analysis in the present species definition in bacteriology. Int $J$ Syst Bacteriol 44, 846-849.

Stackebrandt, E., Frederiksen, W., Garrity, G. M., Grimont, P. A. D. Kämpfer, P., Maiden, M. C. J., Nesme, X., Rossello-Mora, R., Swings, J. $\&$ other authors (2002). Report of the ad hoc committee for the reevaluation of the species definition in bacteriology. Int J Syst Evol Microbiol 52, 1043-1047.
Tamaoka, J. \& Komagata, K. (1984). Determination of DNA base composition by reversed-phase high-performance liquid chromatography. FEMS Microbiol Lett 25, 125-128.

Thompson, J. D., Gibson, T. J., Plewniak, F., Jeanmougin, F. \& Higgins, D. G. (1997). The CLUSTAL_X windows interface: flexible strategies for multiple sequence alignment aided by quality analysis tools. Nucleic Acids Res 25, 4876-4882.

Wayne, L. G., Brenner, D. J., Colwell, R. R., Grimont, P. A. D., Kandler, O., Krichevsky, M. I., Moore, L. H., Moore, W. E. C., Murray, R. G. E. \& other authors (1987). Report of the ad hoc committee on reconciliation of approaches of bacterial systematics. Int J Syst Bacteriol 37, 463-464. 